Carnivore Behavior, Ecology, and Evolution VOLUME 2 



\title{
Carnivore Behavior, Ecology, and Evolution
}

\author{
VOLUME 2
}

\section{John L. Gittleman, EDITOR}

Department of Ecology and Evolutionary Biology

The University of Tennessee, Knoxville

Comstock Publishing Associates, a division of Cornell University Press I Ithaca and London 
Copyright $@ 1996$ by Cornell University

All rights reserved. Except for brief quotations in a review, this book, or parts thereof, must not be reproduced in any form without permission in writing from the publisher. For information, address Cornell University Press, Sage House, 512 East State Street, Ithaca, New York 14850.

First published 1996 by Cornell University Press.

(2) The paper in this book meets the minimum requirements of the American National Standard for Information Sciences-Permanence of Paper for Printed Library Materials, ANSI Z39.48-1984.

Library of Congress Cataloging-in-Publication Data

Carnivore behavior, ecology, and evolution.

(Revised for volume 2)

Bibliography: $\mathrm{p}$.

Includes index.

1. Carnivora. I. Gittleman, John L.

QL737.C2C33 599.74'045 88-47725

ISBN 978-0-801-48216-8 